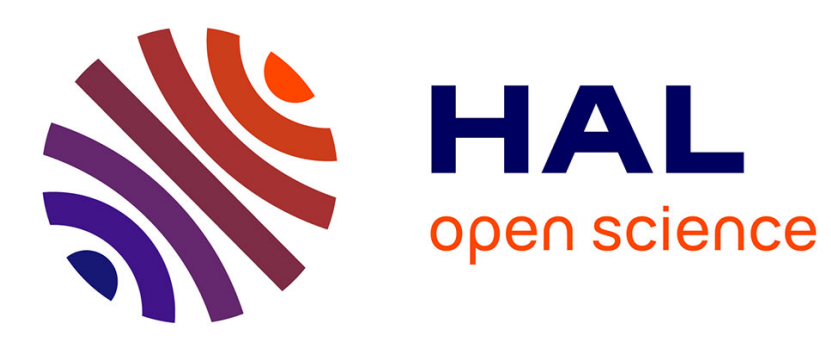

\title{
The New Astronomical Eldorado: The French understanding of American Astrophysics, 1900-1920
}

\author{
Arnaud Saint-Martin
}

\section{To cite this version:}

Arnaud Saint-Martin. The New Astronomical Eldorado: The French understanding of American Astrophysics, 1900-1920. Nuncius. Journal of the History of Science, 2008, 23 (1), pp.91-113. hal00998865

\section{HAL Id: hal-00998865 https://hal.science/hal-00998865}

Submitted on 2 Jun 2014

HAL is a multi-disciplinary open access archive for the deposit and dissemination of scientific research documents, whether they are published or not. The documents may come from teaching and research institutions in France or abroad, or from public or private research centers.
L'archive ouverte pluridisciplinaire HAL, est destinée au dépôt et à la diffusion de documents scientifiques de niveau recherche, publiés ou non, émanant des établissements d'enseignement et de recherche français ou étrangers, des laboratoires publics ou privés. 


\title{
THE NeW ASTRONOMicAL ELDORADO: THE FRENCH UNDERSTANDING OF AMERICAN ASTROPHYSICS, 1900-1920 ${ }^{1}$
}

\author{
ARNAUD SAINT-MARTIN*
}

\begin{abstract}
«L'étranger apprend souvent auprès du foyer de son hôte d'importantes vérités, que celui-ci déroberait peut-être à l'amitié; on se soulage avec lui d'un silence obligé; on ne craint pas son indiscrétion, parce qu'il passe. »

Alexis de Tocqueville, Introduction à De la démocratie en Amérique.
\end{abstract}

\begin{abstract}
At the beginning of the twentieth century, as international competition in astronomy increased, French astronomers were having serious doubts about their international supremacy. Now challenged by the development of interdisciplinary specialties such as astrophysics or geophysics, celestial mechanics had traditionally conferred most of its prestigious status to French astronomy. Considering they were unable to make important contributions on the international scene, a marginal community of French astrophysicists publicly lamented their lack of instrumental resources or the inadequacy of existing ones, as well as poor institutional support. In this paper, I examine the way in which leading French astrophysicists looked at American astronomy. Leading expeditions to the U.S. in the first two decades of century, they wrote reports about the organization of U.S. observatories and shared a fascination for Californian ones. In particular, all believed that George Hale's Mount Wilson Observatory was the only place in the world where astrophysics could really develop: a new "astronomical Eldorado" (as Pulkovo and Greenwich

${ }^{1}$ Publié dans sa version definitive dans Nuncius, Journal of the History of Science, Vol. 23, Issue 1, 2008, p. 91-113.

"A first draft of this paper was presented at the Annual meeting of the History of Science Society, in Vancouver, November 2006. My thanks to David Aubin, Charlotte Bigg, Jérôme Lamy, Fabien Locher, and Laetitia Maison (all members of the research group "Nadirane" (http://www.histnet.cnrs.fr/research/nadirane/)) for their useful comments during the session. I must thank, too, my wife Sarah for her precious assistance in the writing of the paper.
\end{abstract}


had been before). Back home, they sought to import the U.S. research system to transform the French astronomical community as a whole. The invocation of American astrophysics was a pretext for local issues: a prism that coloured national claims.

Keywords : astrophysics, observatory, voyage.

In 1917, after almost a decade of work, Professor George Ellery Hale and the staff of the Mount Wilson Solar Observatory (MWO) finally brought into service the 100-inch telescope. ${ }^{2}$ The giant size of the Hooker telescope and the modernity of the Observatory's facilities caught the attention of astronomers all over the world. The famous science writer Camille Flammarion gave an enthusiastic speech about this technological innovation at the Société Astronomique de France. ${ }^{3}$ He recognized that only the Americans were capable of such a "saut prodigieux dans le progrès de l'optique", because "ils ne doutent de rien, et ils ont raison. Ils vont bientôt en donner à l'Europe une nouvelle preuve éclatante." 4 Flammarion compared the 100-foot coupole of the telescope and the 20-meter dome of the Pantheon in Paris. He highlighted that the job had not been done by the Americans alone: the French St. Gobain Glass Factory provided them with the mirror, which illustrated the "étroite collaboration" between America and France. But the other side of the coin was that the American astronomers were the only ones to own such a treasure. The Europeans could not compete anymore, but though the French astronomers were envious, it was clearly understandable. Indeed, the war was not yet over. The United States joining the Allies in 1917, had encouraged the growth of américanophilie in France. The same year, Aymar de La Baume Pluvinel, the President of the Société Astronomique de France, awarded Hale with the "Janssen Medal." As a representative of the "grande nation américaine" who was fighting against the "barbarie prussienne," Hale was just the man. ${ }^{5}$

After World War I, the European astronomers realized that they were about to be eclipsed by their American colleagues. By the 1900s, the founding of several private observatories in the West (e.g., Lick, Lowell, and MWO) was a sign of this trend. The great success of the Hooker telescope ${ }^{6}$ and the many discoveries made at the MWO confirmed the scientific potential of American astronomy. It also illustrated how much European observatories were outstripped. This widespread feeling should be situated in the context of the internationalisation of science during which American science took the lead on

\footnotetext{
2 Jennie B. Lasby, “The 100-inch telescope at Mount Wilson," Popular Astronomy, 1917, 25:649-651.

${ }^{3}$ Camille Flammarion, "Le plus grand télescope du monde," L'Astronomie, 1917, 31:425-432.

${ }^{4}$ Ibid., p. 432.

${ }^{5}$ Aymar de La Baume Pluvinel to George E. Hale (10 April 1917). Hale papers, California Institute of Technology Archives.

${ }^{6}$ George E. Hale, "The 100-inch telescope of the Mount Wilson Observatory," Popular Astronomy, 1919, 27:635-645.
} 
the world scientific stage- for instance, via the International Research Council. ${ }^{7}$ According to Mary Jo Nye, German, English, and French scientists "now compared their situations unfavourably with that of the United States, envying the youthfulness and energy of the large nation to the west." 8 The French system state-observatory proved to be non-operational (on the levels of instrumental resources and mode of patronage), in comparison to the kind of organization incarnated by the MWO or the Lick Observatory. Institutionalised in the 1880 s, the system was simply inappropriate for the kind of astronomical research which was actually conducted. ${ }^{9}$ This was, in substance, the opinion of the Commission pour le relèvement de l'astronomie française formed in 1920. For its members, the référence obligée to the MWO was a means to pass judgment on this state of affairs and to start a reform of the French system.

This paper studies the French understanding of American astrophysics (and culture) circa 1900-1920. How did the French astronomical community react to this apparent rise? To fully understand, it is necessary to explain the formation of the MWO modèle. I use the word "model" for two main reasons. First, the actors actually use it to portray the MWO. That is why one can treat it as an "emic" concept. The first thing to do here is to historicise its emergence as a category, a symbolic resource for action, and a nationally based "repertoire of evaluation." 10 Who were the MWO admirers? Why did they share an unambiguous attraction to this way of doing astrophysics? Second, the study of the MWO model is a good opportunity to think about the process of comparison, the importation of exemplary ways of organizing the scientific research, and finally the process of community formation in science at the turn of the century. In order to do so, I will focus on the Fourth meeting of the International Union for Co-operation in Solar Research, which took place at the MWO in the summer of 1910. It was a crucial event in the making of the model. A group of astrophysicists came from France and discovered in vivo the management of the American observatories. The voyage in America was an enlightening experience for all of them. MWO, they thought, was the only place in the world where astrophysics could really develop: a new

\footnotetext{
${ }^{7}$ BRIGITTE SCHROEDER-GUDEHUS, Les scientifiques et la paix: la communauté scientifique internationale au cours des années 20 (Montréal: Presses de l’Université de Montréal, 1978).

${ }^{8}$ MARY Jo NyE, “Scientific Decline: Is Quantitative Evaluation Enough?” Isis, 1984, 4:697-708, p. 708. See also, on the rhetoric of decline, HARRY W. PAUL, "The Issue of Decline in Nineteenth-Century French Science," French Historical Studies, 1972, 3:416-450.

${ }^{9}$ For an overview of the institutional regime of the French state-observatories, see JÉRÔME LAMY, L'Observatoire de Toulouse aux XVIII et XIXe siècles. Archéologie d'un espace savant (Rennes: Presses Universitaires de Rennes, 2007); LAETITIA MAISON, Histoire de la fondation et des premiers travaux de l'Observatoire astronomique de Bordeaux (1870-1906), Thèse de doctorat, Université de Bordeaux I, 2004; ARNAUD SAINT-MARTIN, L'office et le télescope. Une sociobistoire de l'astronomie française, 1900-1940, Thèse de doctorat, Université Paris-Sorbonne, to be defended in spring 2008; ID., «Une constitution pour l'astronomie française au tournant du siècle. Socio-genèse d'un champ scientifique », Cabiers d'bistoire. Revue d'bistoire critique, forthcoming.

${ }^{10}$ For an analysis of the cross-national cultural differences, see MiCHÈLE LAMONT, LAURENT THÉVENOT (eds.), Rethinking Comparative Cultural Sociology: Repertoires of Evaluation in France and the United States (Cambridge: Cambridge University Press, 2000).
} 
"astronomical Eldorado" (as Greenwich, Pulkovo and Italian observatories ${ }^{11}$ had been before). Back home, they sought to import the U.S. research system to transform the French astronomical community as a whole.

The paper is constructed as follows: first I examine what was at stake on the French side in the preparation of the Californian meeting. The quasiofficial delegation aggregated several scientists with different interests and motivations. The second part deals with the voyage in America and the discovery of the MWO. The model came into being in this context. The last part examines some reports written after the 1910 conference. These documents explain the success of American science in general, and astronomy in particular, and the best way to import and imitate it in France.

\section{A Key Rendezvous: The French Delegation at the Solar Union MEETING}

In the 1900s, American science was of great interest. The French astrophysicists were concerned by the recent developments of the emergent discipline in the U.S. Around 1904, Henri Deslandres wrote to Hale to announce that he was planning to build a scientific station in the South of France. ${ }^{12} \mathrm{He}$ knew that the director of the Yerkes Observatory was searching for a suitable site to establish a new solar observatory in Southern California, "le pays du Soleil": the Frenchman was anxious to beat his rival in the field they both monopolised. ${ }^{13}$ But Hale got ahead. The MWO was soon founded with the financial support of the Carnegie Institution of Washington. ${ }^{14}$ Prior to 1910, the 60-inch telescope designed by Ritchey, the Snow telescope, the Solar tower telescopes and the optimal geographical location of the observatory contributed to its reputation. But the construction of this material and symbolic capital has not been smooth. Because he wanted to attract scientists and dollars, Hale strategically created an ideal image of the private establishment, as he had done before when he had launched the Yerkes Observatory. ${ }^{15}$ Thanks to Hale's discoveries and political ability, MWO

\footnotetext{
${ }^{11}$ On the Italian paradigm, see LAETITIA MAISON, "Les observatoires italiens en 1875: Un exemple pour le renouveau de l'astronomie française?” Nuncius, 2003, 28:577-602.

${ }^{12}$ Henri Deslandres to George E. Hale (13 April 1904). Hale papers, California Institute of Technology Archives.

${ }^{13}$ A priority dispute on the spectroheliograph opposed Deslandres to Hale since 1894.

${ }^{14}$ The story of the beginnings of Californian observatory is well-known because it was considered as a model in the years following its creation. See, for examples of quasi-official accounts of it, RONALD S. BRASHEAR, "Observatories of Carnegie Institution of Washington," in JOHN LANKFORD (ed.), History of Astronomy. An Encyclopedia (New York \& London: Garland, 1997) p. 119-121; KeVIN KRISCIUNAS, Astronomical Centres of the World (Cambridge: Cambridge University Press, 1988), chap. 6; ALlaN SANDAGE, Centennial History of the Carnegie Institution of Washington. Vol. 1: The Mount Wilson Observatory (Cambridge: Cambridge University Press, 2004).

${ }^{15}$ Donald E. Osterbrock, Pauper and Prince. Ritchey, Hale, and Big Telescopes (Tucson: The University of Arizona Press, 1993).
} 
became one of the leading American scientific institutions. ${ }^{16}$ America was now a part of the "Big Four," which included Great Britain, Germany, and France. ${ }^{17}$ In this context, the Fourth conference of the Solar Union represented a challenge for Hale and the American astrophysicists in general. Hale was eager to show that the MWO deserved its world-class status and that California was the best place on Earth to observe the heavens.

Seven months before the meeting, Benjamin Baillaud, the director of the Observatoire de Paris, urged the Ministre de l'Instruction Publique to finance a mission. ${ }^{18}$ Three years after the last meeting of the Observatoire d'astrophysique de Meudon, Baillaud realized that solar studies had become one of the most important research areas in astronomy, and that French astronomers should participate in the field. Their involvement was guided by scientific and institutional motives. The international co-operation which was planned by the Committee may challenge the pre-eminence of the "Carte $d u$ Ciel," the French-centred international program. ${ }^{19}$ Since the Californian conference would catch the attention of many astronomers from Europe, Baillaud wanted to send a significant number of fonctionnaires, so the French community would appear as influential as possible. The director combined the scientific stakes of the meeting with very general geopolitical considerations. $\mathrm{He}$ was aware that the Ministère de l'Instruction Publique -and the Third Republic in general-attached importance to the propagation of the influence française overseas. And Astronomers thought that they had a role to play in this cultural expansionism. ${ }^{20}$ Therefore Baillaud emphasized that the high-ranking astronomers who would be sent to America needed to "faire prévaloir non seulement leurs idées scientifiques, mais les vues conformes à l'intérêt de leur pays." 21 The director had an agenda in mind; he stressed that "les observatoires des États-Unis d'Amérique, notamment ceux de Washington, de Harvard Collège, du Mont Hamilton, du Mont Wilson et l'observatoire Yerkes sont, dans

\footnotetext{
16 JefFrey Crelinsten, Einstein's Jury: The Race to Test Relativity (Princeton, Princeton University Press, 2006).

${ }^{17}$ John Lankford has compared the relative strength of these leading national astronomical communities in terms of observatories and personnel. In 1907, the US and the United Kingdom possessed more observatories (respectively 102 and 119) than did Germany (45) and France (43). There were a lot more people in the American observatories (294) than in the European ones (161 in the UK, 152 in Germany, and 150 in France). This kind of classification was known by the astronomers at the time. While scientific communities were being "nationalized," this information was of crucial importance for both the leading astronomers and the governments that supported their researches. JOHN LANKFORD, American Astronomy. Community, Careers, and Power, 1859-1940 (Chicago: The University of Chicago Press, 1997), p. 383-386.

${ }^{18}$ Benjamin Baillaud to the Ministre de l'Instruction Publique (18 February 1910). Archives Nationales de France, $F^{17} 17274$.

${ }^{19}$ David H. DeVorkin, "Classification in Astrophysics: The Acceptance of E. C. Pickering's System in 1910," Isis, 1981, 1:29-49, p. 37. On the Carte du Ciel, see IlEANA CHINnICI, La Carte du Ciel: Correspondance inédite conservée dans les Archives de l'Observatoire de Paris (Paris/Palermo: Observatoire de Paris/Osservatorio Astronomico di Palermo, 1999); JerOME LAMY (ed.), La Carte du Ciel, forthcoming.

${ }^{20}$ See Lewis Pyenson, Civilizing Mission. Exact Sciences and French Overseas Expansion, 1830-1940 (Baltimore: The Johns Hopkins University Press, 1993).

${ }^{21}$ Benjamin Baillaud to the Ministre de l'Instruction Publique (28 February 1910). Archives Nationales de France, $F^{17} 17274$.
} 
l'astronomie mondiale, par les moyens exceptionnels dont ils disposent, aux tout premiers rangs." ${ }^{2}$ From 1910, Baillaud recognized that a technological gap was forming between American and European observatories-and not only the French ones. So the "missionnaires" -a sort of official spies- were supposed to look at the "valeur réelle des instruments dont [les Américains] disposent" in situ. $^{23}$ It was a test-experience: the study should help define the measures to be taken to catch up with the astronomical establishments of America.

California was already a mythical place in France before the French astronomy delegation reached it in the summer of 1910. About 1830, French migrants started to settle there. ${ }^{24}$ After the Gold Rush of 1849, the French exodus was quantitatively more significant. The migrants went there to find better life conditions and the freedom they had lost during the Second Empire. In the 1870s, French colonies were well established in the San Francisco area and in the North of California where they worked as traders, winegrowers, farmers, and storekeepers. As early as 1900, California fascinated many people in France. Many experts in the fields of instruction, human sciences, arts, and science travelled through America to understand these new ways of life. Most of them were sponsored by the French state: they were official "missionnaires". ${ }^{25}$ Their job consisted in bringing back useful information about what they saw over there. The trip the astronomers made in 1910 was quite the same thing.

Baillaud chose two astronomers of the Observatoire de Paris to represent the Ministère de l'Instruction Publique. Maurice Hamy, a member of the Académie des Sciences de Paris, was chief of the Laboratoire de spectroscopie stellaire of the Observatoire. Pierre Puiseux, the other missionnaire, taught "physique céleste" at the Sorbonne, and he was used to attending scientific conferences. They both spoke (a little) English; it was a sufficient reason to choose them. Baillaud told them that they ought to inspect a predefined list of observatories and discuss with American leaders the opportunity to participate in the Carte $d u$ Ciel. They went to the New World with the Count Aymar de La Baume Pluvinel, an aristocratic amateur who had been trained by Jules Janssen in the "âge héroïque de la physique solaire"26 during the 1880s. La Baume regularly organized the solar eclipse expeditions supported by the Ministère (and that is why he was a member of the Solar

${ }^{22}$ Benjamin Baillaud to the Ministre de l'Instruction Publique (18 February 1910), in Archive (cit. note 17).

${ }^{23}$ Ibid.

24 ANNICK Foucrier, Le rêve californien. Migrants français sur la côte Pacifique (XVIII'-XXe siècles) (Paris : Belin, 1999).

${ }^{25}$ JEAn-Christophe Bourquin, "National Influences on International Scientific Activity: The Case of the French Missions Littéraires in Europe, 1842-1914,” in CHRISTOPHE CHARLE, JÜrGEN SCHRIEWER, PETER WAgneR (eds.), Transnational Intellectual Networks. Forms of Academic Knowledge and the Search for Cultural Identities (Frankfurt: Campus Verlag, 2004), p. 451-471.

${ }^{26}$ FERNAND BALDET, Notice sur les travaux scientifiques d'Aymar de la Baume Pluvinel (1860-1938) (Orléans : Société Astronomique de France, 1938). On Janssen's astrophysical expeditions, see DAVID AuBIN, "Orchestrating Observatory, Laboratory, and Field: Jules Janssen, the Spectroscope, and Travel," Nuncius, 2002, 27:615-633. 
Union eclipse committee). Also, the physicist had the advantage of knowing Northern America very well.

Hamy, Puiseux, and La Baume were the authorized savants of the République. Six other Frenchmen were invited as well by the Solar Union. They received no grant for their trip. Even though they were not formal members of a state-sponsored delegation, these people were seen as the official représentants of France by their foreign colleagues and the local press. However, each of them had very different motivations and interests. The director of the Observatoire de Paris had no real influence on the way they would lead their trip to the U.S. Henri Deslandres, as I mentioned earlier, was a solar physics pioneer. He was suspicious of Hale's strategy, so his decision to come to California clearly expressed what was at stake, that is to say a struggle for epistemic authority in the field of astrophysics-and there were many potential competitors. Deslandres needed company, so he supported the travel expenses of two regular staff members of the Observatoire de Meudon. Jean Bosler, a solar physicist too, and Pierre Idrac, a young "travailleur volontaire," assisted Deslandres in his tour. Among the French astrophysicists, Bosler would be the best committed to extol the qualities of the American astrophysics and the magnitude of the MWO model. Charles Fabry, the Professor of industrial physics at the Université de Marseille, also moved to America. With Alfred Perot, he was a renowned metrologist, an interferometry expert, and a valued instrument-designer who took an active part in the shaping of the sub-discipline of astrophysics. ${ }^{27}$ As a spectroscopy specialist, Aimé Cotton, a Professor at the École Normale Supérieure, was the last member of this semi-official group. The little cortège would join Henri Chrétien (a member of the Observatoire de Nice) at the MWO. He was already there since the beginning of the year 1910, doing a "stage," in order to learn the American astronomers' methods of research. Chrétien served as an intermediary between the Frenchmen and the Americans.

\section{EXPLORATION NARRATIVES: THE NEW ASTRONOMICAL ELDORADO}

Thus, this micro-community crossed the Atlantic in the summer of 1910. The voyageurs did not keep for themselves the memory of California: they all communicated their thoughts and visions during or after the trip. They wrote letters to their families or committed to diaries the things they saw during the tour. And some of them drew up official or quasi-official reports on their experience of America. Hereinafter, I will use mainly Puiseux's personal correspondence with his wife and family. ${ }^{28}$ One may place these precious

\footnotetext{
${ }^{27}$ Charlotte Bigg, Behind the Lines: Spectroscopic Enterprises in Early Twentieth Century, unpublished Doctoral Dissertation, University of Cambridge, 2002, Part 2.

${ }^{28}$ These private archives are kept by the Association des descendants et amis d'Henri Wallon, and conserved at the Archives du Jura. Permission to use these archive materials was granted by the Association.
} 
documents to the literary genre of the travel narrative. ${ }^{29}$ Like a writer, Puiseux expressed with words what he observed. With his colleagues, he not only visited scientific establishments and contributed to a professional meeting; he also discovered an ecosystem made of human beings, local folklore, material cultures, and natural environment. ${ }^{30}$ The French understanding of American astronomy was full of these different elements. The Frenchmen were strangers in an unfamiliar world; they tried to understand with their own cultural background the essence of a distant cultural model. ${ }^{31}$ They contributed to the (French) invention of the West mythology and the image of the American nation as a whole. ${ }^{32}$ When they got home, they appreciated their own national and cultural identity in a new and different way. The practice of scientific travel spread in the context of the internationalisation of science and the expansion of the industry of tourism at the turn of the century. The culture $d u$ voyage was a component of the practice of the fin de siecle international scientific congresses. ${ }^{33}$ The new astronomical Eldorado merged from the astronomers/tourists' experiences. This way, I argue, the very act of travelling shaped their perception of America.

July 30, Puiseux and La Baume boarded the boat Bretagne at Le Havre. As a solar eclipse hunter, "voyageur devant l'Eternel," La Baume felt comfortable on this "maison flottante" ${ }^{4}$. Although he was an inexperienced traveller, Puiseux wanted to discover the New World. The transatlantic cruise was an experience in itself. The everyday life on the ship was quite solitary, and Puiseux and La Baume socialized with "Yankees" who were going back home after their tour of Europe, a Mexican army officer, and compatriots from the First class: a micro-society was forming. In a diner mondain, Puiseux was proud to introduce himself as "un invité de M. Carnegie." ${ }^{35}$ The astronomer tried to occupy his time: He took some photographs on the deck; he read astronomy books, like the 1909 Annual Report of the Mount Wilson Observatory, and "un dictionnaire publié en Belgique, qui a la pretention de faire connaître tous les astronomes du monde avec l'occupation de chacun d'eux." ${ }^{36}$ As a mathematician and a son of a mathematician, Puiseux had to enquire about the recent advancements in solar physics.

Eight days after the departure, the Bretagne finally reached New York. The first look at the skyline of the city was a disappointing experience: the

\footnotetext{
${ }^{29}$ See FrIEDRICH WOLFZETTEL, Le discours du voyageur. Le récit de voyage en France du Moyen Age au XVIII ${ }^{e}$ siècle (Paris: Presses Universitaires de France, 1996).

30 That is why the Puiseux's correspondence is a "lay" ethnography. CAROLINE B. BRETTELL, "Travel Literature, Ethnography, and Ethnohistory," Ethnohistory, 1986, 33:127-138.

${ }^{31}$ ALFRED SCHÜTZ, L'étranger, trad. (Paris: Éditions Allia, 2003).

32 See TANgi Villerbu, La Conquête de l'Ouest. Le récit français de la nation américaine au XIXe siècle (Rennes: Presses Universitaires de Rennes, 2007).

33 AnNe RASMussen, L'internationale scientifique (1890-1914), Thèse de doctorat, École des Hautes Études en Sciences Sociales, 1995, Tome 1, pp. 174-178.

${ }^{34}$ Pierre Puiseux to Béatrice Bouvet (30 July 1910), in Archive (cit. note 27).

${ }^{35}$ Pierre Puiseux to Béatrice Bouvet (31 July 1910), in Archive (cit. note 27).

${ }^{36}$ Pierre Puiseux to Béatrice Bouvet (2 August 1910), ibid. Puiseux referred to the book edited by the Brussels astronomer PAUL STROOBANT, Les observatoires astronomiques et les astronomes (Bruxelles: Hayez, Observatoire royal de Belgique, 1907).
} 
monuments and the docks, "immenses constructions en planches peintes de couleurs noirâtres et sans frontières", "[lui] font, avec leur forme généralement cubique, une impression marquée d'uniformité et de laideur." ${ }^{37}$ Having arrived a few days before, Hamy's first impression was on the contrary quite "favorable." He wrote to his son that "[les hautes maisons] ne sont pas artistiques, il est vrai, mais elles donnent une idée nette de la puissante énergie de ce pays et de sa richesse." ${ }^{38}$ The voyageurs confirmed their preconceived opinion. The sea gate to America incarnated the emergence of an advanced technological nation.

The organization and the constraints of the tour terrified Puiseux; but happily for him, La Baume took the lead. And so the long trip by transcontinental railways could really start. After staying in Montreal for only one day, they crossed then the Canadian territory during the second week of August. Both a scientist and a businessman, La Baume stopped in Winnipeg "pour visiter une des exploitations agricoles où il [avait] des intérêts." 39 Puiseux continued alone for a while. From the train, he contemplated the vast plains; he visited some national parks (e.g., Barnff) and discovered the landscapes of the Canadian Rockies. About the same time, Hamy and Bosler were exploring Yellowstone Park. Glacier House was a revelation for Puiseux, a kind of Eden "aussi joli que n'importe quelle vallée Suisse, mais différent." ${ }^{40}$ This land was full with natural resources. Puiseux observed as well "les types variés des Américains de l'Est et de l'Ouest, ceux-ci plus animés, plus sociables et se rapprochant de nos méridionaux." Although he enjoyed the excursion, Puiseux thought that the Autochthons' customs were vulgar and prosaic, lacking the kind of dignity which made the miracle of French civil culture; for him, Yankee saloon sociality was the exact opposite of the French salon civility. Thus, Puiseux portrayed bluntly the way of life in the New World. Since La Baume left him at Winnipeg, Puiseux could not share his views with other people. And the Americans "[n'avaient] pas la patience d'insister quand ils voyaient qu' $[i l]$ ne comprenait pas". ${ }^{41}$

The solitude finally ended when he found La Baume again on the road to the Pacific Ocean. On August 20, they arrived in Vancouver. For Puiseux, the city looked like "toutes les villes américaines, riche en hautes bâtisses carrées, en lignes de tramways tapageurs, en réclames voyantes." ${ }^{2}$ Since the arrival, he and his friends saw the uniform and massive architecture of the cities as the metonymic figuration of America. Fortunately, Victoria gave a nicer image of British Columbia. It was the first place where Puiseux felt signs of "sympathie." Hugging the Pacific coast, they finally arrived in California, on August 24. Puiseux marvelled at the atmosphere in the town of San Francisco; he admired as well the way Americans had managed to rebuild the city on the ruins of the 1906 earthquake-another proof of the industrial superiority of America. The

\footnotetext{
${ }^{37}$ Pierre Puiseux to Béatrice Bouvet (7 August 1910), in Archive (cit. note 27).

${ }^{38}$ Maurice Hamy to André Hamy (23 July 1910). Private archives of Michel Hamy.

${ }^{39}$ Pierre Puiseux to Béatrice Bouvet, (12 August 1910), in Archive (cit. note 27).

${ }^{40}$ Pierre Puiseux to Béatrice Bouvet, (16 August 1910), ibid.

${ }^{41}$ Pierre Puiseux to Béatrice Bouvet (17 August 1910), ibid.

${ }^{42}$ Pierre Puiseux to Béatrice Bouvet (20 August 1910), ibid.
} 
next day, they met with the President of the University of Berkeley and the astronomy Professor Leuschner; "ces messieurs se rappellent bien avoir vu MM. Picard, Gard, Poincaré et les distractions de ce dernier semblent être demeurées légendaires chez eux." 43 They all very much enjoyed socializing with several American colleagues, but they knew that their real mission was only beginning.

William Campbell, the director of the Lick Observatory, invited the French group for a two-day visit. From San Francisco, they took the train to get to the busy San Jose. Hamy (back from a trip in Alaska), Idrac, and a Russian astronomer were already waiting for them there. The twenty-five kilometre road to Mount Hamilton Peak was a hellish experience, but they finally arrived at the top of the mountain. Europeans could then really see this place they could only imagine before that by reading the formal reports of the Observatory. ${ }^{44}$ Far from industrial cities, the culture and community life of the Lick was undisturbed. The Campbell family was very pleasant with their guests, even if no one could speak French; the music played by Miss Campbell's phonograph and the luncheons engaged communication. ${ }^{45}$ Campbell guided the French men in the facilities of the observatory. The nightuse of the lunette, the Crossley refractor, the Mills spectrograph, and the equatorial confirms Puiseux's expectations:

La pureté du ciel est en effet fort au-dessus de ce que nous avons ordinairement à Paris; les instruments sont plus puissants et remarquablement bien agencées. [...] Les dépenses qu'il a fallu faire pour organiser là-haut des réservoirs d'eau alimentés par des pompes, de puissantes machines électriques, ont été formidables, mais la Californie est riche et il s'y fait encore tous les jours de grandes fortunes [...]. La tranquillité dont jouissent les observateurs sur le sommet, dont l'accès est plutôt long et dispendieux, est aussi favorable au travail. ${ }^{46}$

Campbell showed the entire logistics of the site. And his French hosts were very much impressed. Deslandres, also invited at Lick, will later compliment Campbell for the "qualities si desirables de son observatoire modele" which he could "observer de ses propres yeux". ${ }^{47}$ The organization was more "traditionnelle" than was the one of the MWO, according to La Baume, ${ }^{48}$

${ }^{43}$ Pierre Puiseux to Béatrice Bouvet (24 August 1910), ibid.

${ }^{44}$ In a letter sent to Campbell from Montreal, La Baume mentions "le splendide observatoire au sujet duquel il a tellement entendu parlé.” Aymar de La Baume Pluvinel to William Campbell (11 August 1910). Mary Leane Archives of the Lick Observatory.

${ }^{45}$ For descriptions of the Lick Observatory "culture" and moral economy (and the important role played by Mrs. Campbell), see Alex Soojung-Kim PANG, "Gender, Culture, and Astrophysical Fieldwork: Elizabeth Campbell and the Lick Observatory-Crocker Eclipse Expeditions”, Osiris, 1996, 11:17-43; DONAld E. OSTERBROCK, John R. GuSTAFSON, W. J. SHILOH UnRuh, Eye on the Sky: Lick Observatory's First Century (Berkley: University of California Press, 1988), chap. 8.

${ }^{46}$ Pierre Puiseux to Béatrice Bouvet (25 August 1910), in Archive (cit. note 27).

47 Henri Deslandres to William Campbell (21 September 1910). Mary Leane Archives of the Lick Observatory.

${ }^{48}$ Aymar de La Baume Pluvinel to Benjamin Baillaud (7 septembre 1910). Archives de l'Observatoire de Paris, MS 1060, V-B-1. 
but the "petite compagnie" of the Lick was exemplary in demonstrating discipline and involvement in the collective work.

On August 28, in Pasadena, the French group got bigger, with the arrival of Bosler, Chrétien, Cotton, Deslandres, and Fabry. The four-day Congress would soon start. The whole community of British, Dutch, German, Italian, and Russian delegates formed a "Tour de Babel"49. The American astronomers came in very large numbers, followed by the French and German delegations. ${ }^{50}$ The meeting caught the attention of the local newspapers and various astronomical periodicals. ${ }^{51}$ The reports published in these journals presented the official and visible version of the event. Puiseux's correspondence provides a more intimate account. The Parisian astronomer started by visiting the MWO Laboratory at Pasadena. Puiseux thought that the visit was a kind of demonstration of force:

On a dépensé ici des millions et fort intelligemment, à tel point qu'on ne craint plus guère les concurrences. Aussi étale-t-on sans réticence sous les yeux, ce que ne font pas les constructeurs français. On trouve là les machines les plus perfectionnées pour tourner ou creuser le métal. Ces machines sont en action sur de vrais instruments, car l'Observatoire du Mont Wilson qui a déjà le télescope le plus puissant du monde est en train de s'en donner un encore trois fois plus grand [Puiseux points bere to the Hooker telescope]. ${ }^{52}$

The exhibition of the many instruments in the MWO ecological environment increased the symbolic value of the establishment as a model. After having contemplated the laboratory, the assembly could then ascend the mountain on foot, by horse, or car. There, the congressists could discover again other new instruments. The 150-foot Tower telescope was the most unusual instrument-it confirmed, again, the shrewdness of the American instrumentalists. ${ }^{53}$

Hale wanted to stimulate personal contacts and informal discussions. ${ }^{54}$ It was a very unusual modus operandi for the Frenchmen who were familiar with the formal conferences organized at the Observatoire. English was the main language. Puiseux was designated translator and secretary by Schuster. However, it was hard for him to intervene in the debates, since his English was too rudimentary ("on doit souvent trouver que je responds à côté"). For

\footnotetext{
49 Pierre Puiseux to Béatrice Bouvet (28 August 1910), in Archive (cit. note 27).

${ }^{50}$ Here is the national distribution: United-States, 46; France, 9; Germany, 9; Great Britain, 8; Russia, 3; Canada, 2; Austria, Holland, Italy, Spain, Switzerland, 1 each. See C. A. CHANT, "The Mount Wilson Conference of the Solar Union", Journal of the Royal Astronomical Society of Canada, 1910, 4:356-372, p. 360.

${ }^{51}$ For instance, C. A. CHAnT, "The Mount Wilson Conference of the Solar Union" (cit. note 49) ; H. C. WILSON, "The Fourth Conference of the International Union for Co-operation in Solar Research", Popular Astronomy, 1910, 18:489-503.

52 Pierre Puiseux to Béatrice Bouvet (29 August 1910), in Archive (cit. note 27).

53 H. C. WILSON, "The Fourth Conference of the International Union for Co-operation in Solar Research" (cit. note 50), p. 492.

${ }^{54}$ C. A. Chant, “The Mount Wilson Conference of the Solar Union” (cit. note 49), p. 362.
} 
instance, he could not exchange with Pickering, Backlund, Dyson, Kapteyn, or Turner during the stellar magnitudes session. And Puiseux was not the only savant lost in translation. Deslandres failed to convince the experts of the spectroheliographic research session to create a new "Committee on the Study of the Solar Motions." ${ }^{55}$ His irrepressible monolingualism did not help, nor his tendency to celebrate his own researches. Puiseux noted ironically that Deslandres "fait une communication longue, précipitée, où il reprend l'bistoire de ses travaux depuis 17 ans, dans un anglais que les Américains comprennent peu ou pas du tout. Il est écouté avec une impatience assez peu dissimulée et plusieurs déploient des journaux." 56 Behind the peaceful scientific discussion, Deslandres was very harsh with Hale's institutional strategy and scientific works. He confided later to Campbell some thoughts about the "comédie bumaine des congrès," which reveals how much he was irritated by Hale's "syndicat."

Hale est décidément un struggle for life de premier ordre ; il emploie tous les moyens. Il est extrêmement habile, ayant les qualités d'un homme politique et d'un savant, mais surtout les qualités d'un homme politique. Sur le terrain scientifique, il a fait de grandes découvertes mais, en général, il les interprète mal; et tous ses appareils sont fort compliqués. Il a organisé très habilement le congrès solaire, avec un petit groupe compact de la Société astronomique de Londres, avec des intérêts communs, mais qui lui sont inférieurs, ce qui lui assure la suprématie. ${ }^{57}$

The struggle for institutional authority was quite intense. Deslandres was not in St. Louis when the "Committee on Solar Research" was founded in 1904. Since he could not take part in the Exposition there, ${ }^{58}$ Deslandres had difficulty laying down his requests. Because he could not speak English, he could not serve as a "chairman." This linguistic obstacle was crucial while the emergent field of astrophysics was being structured by the English-written periodical Astrophysical Journal. Nonetheless, other Frenchmen seemed more successful. Fabry defended the "French interests" more efficiently by setting up spectroscopic standards. ${ }^{60}$ Finally, one of the most important results of the Conference was the extension of the researches to the entire astrophysical field, which would integrate solar physics, the spectral classification and the

\footnotetext{
55 H. C. WILSON, "The Fourth Conference of the International Union for Co-operation in Solar Research" (cit. note 50), p. 499-500; for the transcription of the debates, see the "Proceedings of the Conference," Third Session, Transactions of the International Union for Cooperation in Solar Research, 1910, 3:79-105, p. 82.

${ }^{56}$ Pierre Puiseux to Béatrice Bouvet (2 September 1910), in Archive (cit. note 27).

57 Henri Deslandres to William Campbell (21 September 1910). Mary Leane Archives of the Lick Observatory.

${ }^{58}$ Henri Deslandres to George E. Hale (31 August 1904). Hale papers, California Institute of Technology Archives.

59 Henri Deslandres to William Campbell (21 September 1910), Mary Leane Archives of the Lick Observatory.

${ }^{60}$ BIGG, Behind the Lines (cit. note 26), pp. 43-44.
} 
investigation of the stars. At the end, Turner suggested that the Solar Union and Astrographic Chart should join. ${ }^{61}$ Baillaud's worries appeared wellfounded: the Californian meeting had led to a new definition of astrophysics as a unified discipline. And this epistemological change occurred in the most ultimate astronomical place in the world.

After the Conference, the French finally separated. It was clear that the visit of the MWO was the main episode of the mission. Some took the train to New York City after having discovered the countryside outside Los Angeles, while others went to Arizona to see the Grand Canyon. La Baume had not yet left Pasadena and already sent a brief report to Baillaud. ${ }^{62}$ He underlined the creation of the new spectral classification committee of which Hamy was a member. "L'Europe a été bien représentée," according to La Baume. His description of the "l'bôtel du Mont Wilson" and its scientific equipment was very precise. For him, there was no obvious difference between the quality of the images taken in California and at the Observatoire de Meudon. However, La Baume admitted that the MWO had the "Soleil avec lui." And Ritchey's photographs were amazing to him: "le jour où M. Ritchey abordera la photographie des planètes, il résoudra bien des problems. Aussi je considère que ce serait peine perdue que de faire des travaux de ce genre en France."

Puiseux and Hamy planned a visit to the Yerkes Observatory, in Wisconsin. When they approached Flagstaff, Arizona, they recognized the Lowell Observatory on the Mars hills but, according to Puiseux, the private observatory did not deserve a halt. ${ }^{63}$ Anyway, they had already seen the Eldorado. Before leaving America, Puiseux wrote to Campbell, in the name of the French and European astronomers, that he would "remporte $r$ ] en Europe beaucoup d'excellents souvenirs, mais ceux de l'Observatoire Lick brillent, si j'ose le dire d'un éclat tout particulier." ${ }^{64}$ In the same tone, La Baume expressed "l'admiration la plus profonde pour le bel établissement que vous [Campbell] dirigez." ${ }^{5}$ These compliments sur le vif synthesized a collective attitude. When they got home, the explorers put together the things they saw and made a post hoc modèle. It was then time to draw conclusions from their experience of America.

THE AMERICAN MODEL AS A PRETEXT FOR CULTURAL REFLEXIVITY AND LOBBYING

The in situ observation of the American observatories has been a crucial event in the making of the MWO myth. After nearly a week at the MWO, the

${ }^{61}$ C. A. Chant, “The Mount Wilson Conference of the Solar Union” (cit. note 49), p. 368.

${ }^{62}$ Aymar de La Baume Pluvinel to Benjamin Baillaud (7 septembre 1910), in Archive (cit. note 47).

${ }_{63}^{63}$ Pierre Puiseux to Béatrice Bouvet (8 September 1910), in Archive (cit. note 27).

${ }^{64}$ Pierre Puiseux to William Campbell (22 September 1910). Mary Leane Archives of the Lick Observatory.

${ }^{65}$ Aymar de La Baume Pluvinel to William Campbell (7 September 1910). Mary Leane Archives of the Lick Observatory. 
Frenchmen had a clear idea of what the model observatory should be like. What did the French bring back from their stay in California? In this part, I will focus on the writings of Bosler and La Baume. They became the advocates of the Americanization of the French system of state-observatory in the 1920s.

As an immediate result of his tour in the U.S., Bosler, an astronome physicien of the Observatoire de Meudon, published a long paper on "Les récents progrès des méthodes astrophysiques aux États-Unis." 66 The image he gave of the organization of the American observatories that he had visited (Harvard, Lick, Yerkes, Lowell, and MWO) was very positive. These establishments looked like factories managed by what Edward Pickering, the director of the Harvard College Observatory, called "eminently practical men." "67 "Un de leurs traits communs, Bosler stressed, est l'extrême perfection des moyens mécaniques, l'ingéniosité toujours en éveil et l'absence de tout esprit de routine dont les constructeurs ont à tout instant fait preuve." ${ }^{68}$ The physicist was fascinated by the way the "méthodes industrielles" were applied in the science of astrophysics. It showed "le génie d'un peuple si bien doué à la fois pour les grandes affaires et pour tout ce qui touche à la mécanique." ${ }^{69}$ The model observatories illustrated the valuable interaction between industry and science, since they were situated close to industrial cities that provided them with raw materials and technological equipments. Although the giant telescopes and the mechanical equipments did not possess the aesthetic sophistication of the French instrumentation, these technologies were more efficient. The 150-foot Tower telescope illustrated the creativity and the absence of "esprit de routine" that characterized the American "constructeurs." The Laboratory of the MWO was the state of the art in terms of the rational organization of scientific work. ${ }^{70}$ It was the kind of méthodologie the French observatories has to import to be more modern. Why was astrophysics research developing so quickly in America? For Bosler, the "générosité royale" and "l'influence positive" of the "riches industriels Américains" was a key to understanding that. ${ }^{71}$ Science was of great interest and concern for people like Andrew Carnegie or John Hooker. Bosler lamented that the French patrons kept their money to themselves, when "leurs largesses pourraient être, ne serait-ce qu'en partie, plus judicieusement distribuées, dans l'intérêt du prestige moral du pays, en dons à des institutions scientifiques qui luttent péniblement pour soutenir un passé glorieux."72 By pointing that out, Bosler targeted in some way the system of state-observatory. The apology of the private American astronomy economy served a political purpose; the physicien showed that the French savants could escape from the bureaucratic organization of the establishments like the Observatoire de Paris.

\footnotetext{
${ }^{66}$ JEAN BOSLER, "Les récents progrès des méthodes astrophysiques aux États-Unis," Revue générale des sciences pures et appliquées, 1911, 22:102-113.

${ }^{67}$ EDWARD PICKERING, “The Future of Astronomy,” Popular Science Monthly, august 1909.

${ }^{68}$ BOSLER, "Les récents progrès des méthodes astrophysiques aux États-Unis" (cit. note 65), p. 113.

${ }^{69}$ Ibid., p. 102.

${ }^{70}$ Ibid., p. 111.

${ }^{71}$ Ibid., p. 113.

72 Ibid., p. 113.
} 
He mentioned also the positive spur of the spirit of entrepreneurship in astronomy: "chercher des fonds est pour leurs savants [de l'Amérique] une occupation toute naturelle, presque un plaisir; les employer à construire de nouveaux instruments en est un autre." 73 Pickering was the perfect example of this attitude, since he naturally managed to a raise lot of money for the Harvard College Observatory from philanthropic donors. ${ }^{74}$ On the contrary, the French were reluctant to this activity. They were just waiting for the money "to fall down from the (governmental) sky." Bosler underlined the effects of the ethos of his "nés fonctionnaires" colleagues. For him, the main origin of the rise of the American astronomy was cultural. The pragmatism and the inventiveness of the American culture were a good incentive to science. The French simply had to recognize that in some ways, people outside France may have found better methods to organize the sciences. Bosler finished his paper by a plea for humility.

The year after the Congress, La Baume Pluvinel told the story of his tour in the U.S. to the public of amateur astronomy. ${ }^{75}$ The astronomer reviewed all the establishments that he visited, chronologically, from coast to coast, focusing on both the instruments and the organization. First he began with an idea which was now common: these "observatoires sont, ainsi que vous le savez, les mieux outillés du monde." In comparison to other observatories, ${ }^{76}$ the MWO clearly appeared as the most important one. After all, wrote La Baume, the establishment was the "but de notre voyage." ${ }^{7}$ The rhetoric was hyperbolic. The MWO had "le plus puissant réfracteur qui existe. Le miroir a été travaillé par Ritchey et est une merveille d'optique."78 In France, there were no instruments like that-the grande lunette was an exception. Why was American astronomy so successful? With Bosler, La Baume emphasized the "rôle considérable que joue l'initiative privée en Amérique" : si l'on excepte l'observatoire de Washington, qui appartient à l'État, tous les autres établissements astronomiques américains ont été fondés par de généreux donateurs qui se sont cotisés pour réunir les fonds nécessaires à leur création."79 This was an important difference with the French system. The intervention of the state in the organization of the scientific professions in France was structural. $^{80}$ As an amateur, La Baume insisted that another system was possible. However, his point of view on the American pragmatism applied to

\footnotetext{
${ }^{73}$ Ibid., p. 102.

${ }^{74}$ See Howard Plotkin, "Edward C. Pickering and the Endowment of Scientific Research in America, 1877-1918," Isis, 1978, 1:44-57.

75 Aymar DE LA BAume Pluvinel, Une visite aux observatoires des États-Unis (Paris: Société Astronomique de France, 1911).

${ }^{76} \mathrm{La}$ Baume presents Harvard College, Blue Hill, Washington Naval Observatory, Georgetown, Allegheny, Brashear, Yerkes, Lowell, Lick, and Mount Wilson.

${ }_{77}^{7}$ LA BAUMe Pluvinel, Une visite aux observatoires des États-Unis (cit. note 74), p. 30.

${ }^{78}$ Ibid., p. 39.

${ }^{79}$ Ibid., p. 3.

${ }^{80}$ See ROBERT FOX, « Science, the University, and the State in Nineteenth-Century France », in GERALD GEISON, Professions and the French State, 1700-1900 (Philadelphia: University of Philadelphia Press, 1984), pp. 66-122.
} 
the organization of the sciences was ambivalent. In those lectures he gave at the Sociéte Astronomique de France, he interpreted the cultural and axiological conditions of the private foundation system. The discourse was ironical: the aristocrat caricatured the American patrons of science and scientists' standards of behaviour. Why did they give substantial funds to astronomy? Here is the very suggestive explanation of La Baume:

Mais on peut se demander pourquoi les Américains, gens essentiellement pratiques, s'intéressent à une science aussi éminemment spéculative que l'astronomie. Au fond, à part de rares exceptions, les Mécènes qui donnent si largement pour l'astronomie sont absolument ignorants des choses du ciel. Ainsi, M. Lick n'avait jamais regardé un astre dans une lunette lorsqu'il fonda son observatoire [...]. En réalité, si les Américains donnent si largement pour l'astronomie, c'est qu'ils savent que le vieux monde leur reproche d'être trop pratiques et trop intéressés ; aussi sont-ils heureux de pouvoir montrer, à l'occasion, qu'ils sont accessibles au culte de l'art et de la science. Voici comment la vanité n'est peut-être pas tout à fait étrangère au développement de la science astronomique aux États-Unis. ${ }^{81}$

This striking assertion helps to understand the stereotypic representation of the American culture among French scientists. La Baume suggests that the patrons of science were in the habit of warding off their moral state by some generous gifts to science. The desire for recognition and vanity were "en réalité" the impure origin of the philanthropic politics of knowledge. La Baume affirmed here the moral superiority of the Old World over the "New" one. Even though La Baume noticed the productiveness of the Californian observatories, he believed that morally the ulterior motive of the system of patronage was futile. In a very long paper published in December 1911 about the MWO, the physicist Louis Houllevigue used the same argument. In a tocquevillian fashion, he stated that "l'esprit profondément religieux des Yankees s'intéresse aux merveilles du Ciel 'qui disent la gloire du Créateur' et leur caractère pratique dérive cet enthousiasme vers les recherches scientifiques." ${ }^{22}$ So the growth of the American science was just a question of money: "c'est à coups de millions que Hale a gagné ses victoires sur l'inconnu; je sais plus d'un laboratoire français où les études solaires seraient poussées plus vigoureusement si les ressources ne lui étaient pas mesurées avec parcimonie; c'est ainsi que la patrie de Laplace et Le Verrier [...] est en train de perdre une prééminence qu'elle devait au génie de ses fils de naissance." 83 The interpretation is meaningful. According to John Servos, the very empiricist "Baconian character of American scientific work" was constitutive of the epistemology of American physics before the $1930 \mathrm{~s}^{84}$

\footnotetext{
${ }^{81}$ La Baume Pluvinel, Une visite aux observatoires des États-Unis (cit. note 74), p. 4.

${ }^{82}$ Louis Houllevigue, "L’Observatoire du Mont Wilson," La Revue de Paris, 1911, 28:547-562, p. 549.

${ }^{83}$ Ibid., p. 562.

${ }^{84}$ JOHN W. SERVOS, "Mathematics and the Physical Sciences in America, 1880-1930," Isis, 1986, 4:611629, p. 614
} 
Because the Americans were "des hommes éminemment pratiques" (Bosler), astrophysics was a technical activity for them. Although they excelled in observational astronomy and laboratory experiments, they could not develop theoretical programs. Americans had to attract foreign theorists like the Dutch astronomer Jacobus Kapteyn. ${ }^{85}$ The logical inference of this idea is that if the French astronomers had the money, they would surpass the Americans. And it was a sort of challenge for the French, since they alleged that the Yankees were trying to dominate the world of science. An attitude that Hale personified: "la vie de Hale est vraiment représentatif du monde américain, qui porte autant d'audace à conquérir la science qu'à imposer à l'univers les produits de son industrie." 86

The MWO model was highly idealized. One may stress some facts which eventually help to picture this history in a more balanced way. In reality, the erratic construction of the mirror of the 100-inch telescope showed the problems the staff of the establishment had to face before 1917. ${ }^{87}$ But Hale managed to hide these technical hitches. On the other hand, was MWO really a paradise for solar physicists?, a place where astronomers performed full-time research? As David DeVorkin has demonstrated, Hale's relative failure in attracting physicists or laboratory spectroscopists prior to 1922 is instructive. ${ }^{88}$ As an "applied science," the astrophysics of the MWO was at odds with the American physics community. More generally, and contrary to Bosler's opinion, the life conditions on the top of the mountain were not so idyllic; the routine, the monastic isolation and the single life were a kind a torture for the staff of the MWO with the bustling Los Angeles as a neighbour not far away. The endowment of the astronomical research was not as easy as Bosler and his friends imagined. Pickering's relative failure to stimulate a national endowment and a cohesive support program for the American astronomy revealed the limits of the private funding system. The moral economy of donation implied a dependency between the donator and the receiver. The "individualistic prewar style of science patronage" 89 could have negative effects. For instance, the "politics of knowledge" 90 of the Carnegie Institution fashioned the advancement of science. The scientists had to compose with that. On a more individualistic level, generous donors' personal desires could disturb the organization of the observatories. At the MWO, for example, the rich Los Angeles industrialist Hooker was very anxious to tell everybody that his 100inch telescope was finally ready. The Americans were not so satisfied with

\footnotetext{
${ }^{85}$ DaVid H. DeVorkin, "Internationalism, Kapteyn and the Dutch pipeline," in P.C. VAN DER KrUIT, K. VAN BERKEL (eds.), The legacy of J.C. Kapteyn. Studies on Kapteyn and the development of modern astronomy (Dordrecht: Kluwer, 2000), pp. 129-150.

${ }^{86}$ LOUis Houllevigue, "L’Observatoire du Mont Wilson" (cit. note 81), p. 547.

${ }^{87}$ Osterbrock, GUSTAFSON, SHILOH UnRuH, Eye on the Sky (cit. note 44), pp. 103-162.

${ }^{88}$ David H. DeVorkin, "Quantum Physics and the Stars (V): Physicists at Mount Wilson Prior to 1922," Journal for the History of Astronomy, 2000, 4:155-188.

${ }^{89}$ See Robert E. KOHLER, "Science, Foundations and American Universities in the 1920s," Osiris, 1987, 3:135-164.

${ }^{90}$ Ellen Condliffe Lagemann, The Politics of Knowledge: The Carnegie Corporation, Philanthropy, and Public Policy (Middletown: Wesleyan University Press, 1990).
} 
these arrangements. Whereas the French desperately sought to entice the mécènes, the Americans wanted the federal government to intervene and cooperate more in their affairs. However, Bosler, La Baume and the other French astronomers could not see it. They accentuated only elements they wanted to see.

The French thought highly of American astronomy. But this attraction was not one-sided. The Americans were also concerned with the advancement of French astronomy. For example, the construction of the 60-inch telescope of the Yerkes Observatory was partly motivated by the establishment of the big lunette of the Exposition universelle de Paris. In 1899, Hale informed Harper, the President of the University of Chicago, that the patron of science Charles Yerkes "believed the Paris telescope will overshadow ours [the 40-inch telescope of the Yerkes Observatory], and would be only too glad of a chance to outdo it." 91 Even if the French instrument was "designed for popular amusement," the physicist could not think about this progress without making it obvious. One should also consider the importance of the technological and commercial exchanges between the American astronomers and the French instrument makers. The MWO-St. Gobain contract was an example among others. In the 1900s, the American observatories used to acquire equipments and devices made by constructeurs like Gautier, Prin, Secrétan, etc., or the photographic plates manufactured by the renowned Lyon Lumières Company.

After World War I, the foundation of the International Research Council facilitated the solidarity between the Allies. The developments of a new form of "internationalism", which notably excluded the Germans and then created two "hostile camps," institutionalised the pre-eminent position of American science. ${ }^{92}$ In this context, a process of Americanization had great effects on the Inter-Allies' self-perception and interior policy. ${ }^{93}$ The positive reference to America (science and society in general) among the French scientific community became a commonplace. And the Californian sociotechnological Eldorado ${ }^{94}$ was the trendiest component of this fascinating stereotype. Again, the making of the model was progressive. The 1910 voyage was, as I have argued, a decisive moment in the making of it, at least in the French scientific community. The model emerged because cultures were in contact; French could watch in situ the American astronomy community they could only imagine before.

\footnotetext{
${ }^{91}$ George E. Hale to William R. Harper (9 may 1899). George E. Hale Papers, University of Chicago Library.

92 PAUl Forman, "Scientific Internationalism and the Weimar Physicists: The Ideology and Its Manipulation in Germany after World War I," Isis, 1973, 2:151-178; DANIEL J. KevLES, “Into Hostile Political Camps': The Reorganization of International Science in World War I," Isis, 1971, 1:47-60.

${ }^{93}$ See Olivier ZunZ, Why the American Century? (Chicago: University of Chicago Press, 1998).

${ }^{94}$ John L. Heilbron, RoberT W. SeIDEL, Lawrence and his Laboratory: A History of the Lawrence Berkley Laboratory (Berkley: University of California Press, 1989), part I.
} 
This model integrated a set of basic assumptions and principles on the MWO. The souvenir of the establishment became fuzzy only years after the original experience. The original essence of the MWO was then filtered by the individual and collective memory: the geographically distant site transformed into a legendary form. By definition, a model is a simplification of reality; the model makers accentuate the positive details and occult the negative ones. When they invented the new astronomical Eldorado, the astronomers took several elements. The French understanding of American astrophysics was to some extent fantasized: the macro-social entity "American astronomy" they had observed was a mixture of moral judgments and commonly held representations about places, people customs, and folk culture. From the French point of view, the rise of American astrophysics results from the complex interaction of self-confidence, industrial methods, pragmatism, patrons' vanity, great climatologic conditions, an ability to expanse money, and faith in God. The MWO model was indeed the concrete abstraction of America.

The construction of the MWO model had also pragmatic ends. The positive reference to Eldorado had to be useful. When the Académies des Sciences urged the government to revive astronomy in the country, in 1920, the MWO and the kind of organization it symbolized became the common topos of the debates among the French astronomers. Deslandres, then Président of the Académie, made the first move by writing a long diagnostic report on the socalled "crisis" of French astronomy. What was the best method to adopt? For Deslandres, the MWO was the best "model" to "imitate" (sic). ${ }^{95}$ In the same mood, Baillaud believed, too, that "tout travail fait en Amérique devrait pouvoir être fait en France." ${ }^{96}$ He wanted to build a new Observatoire de Paris in the image of the MWO. About 1923, an independent and private committee helped to plan the foundation of the "biggest observatory in the world." The appointment of Ritchey in 1924 by the mécène Dina for the construction of the mirror was a first decision that would lead in theory to a French version of the MWO. But the French astronomers were not on time. While they were looking for an appropriate place in the South of France to establish the hypothetical observatory, the astronomers of the MWO were already planning the construction of the 200-inch telescope (endowed by the Rockefeller Foundation), which would be later installed at the Mount Palomar Observatory-again, a "newer" astrophysical Eldorado.

\footnotetext{
${ }^{5}$ Henri Deslandres, Sur l'amélioration des études astronomiques en France (Orléans: Imprimerie Henri Tessier, 1926). See ARnaud SAINT-Martin, “La phase critique de la Carte du Ciel à Paris, 1920-1940,” in La Carte du Ciel, edited by Jérôme Lamy (forthcoming).

${ }^{96}$ Eleventh session, 12 July 1920, report of the "commission des observatoires", Archives Nationales de France, $F^{17} 13572$.
} 